\title{
Activating RET Mutation
}

National Cancer Institute

\section{Source}

National Cancer Institute. Activating RET Mutation. NCI Thesaurus. Code C129702.

A change in the nucleotide sequence of the RET gene that results in constitutive protooncogene tyrosine-protein kinase receptor Ret-dependent signal transduction and activation of downstream signaling pathways. 